\title{
CURRENT RUSSIAN POLICY IN THE AREA OF COUNTER-OFFICIAL CRIMES
}

\author{
Artur Gennadevich Bezverkhov
}

Faculty of Law of the Samara National Research University named after academician S. P. Korolev, Samara, Russia

OMESTE

JEL Category: K14

\begin{abstract}
Annotation
Service activities are carried out in various spheres of public life and affect all the diversity of rights, freedoms and other socially important goods, relations and values. Therefore, the interests of the service are protected by legal means of different sectoral nature, including criminal law. At the same time, clarity in distinguishing between crimes and misconduct in the service is extremely important for law enforcement. However, the issue of distinguishing between official crimes and misdemeanors is one of the poorly developed ones in doctrine and practice. A clear distinction between crimes and misdemeanors in the service involves specifying the objective features of the composition of official offenses. The concretization here is justified by the need to exclude subjectivity on the part of practitioners, both their mistakes and outright abuses. It is also important to take into account the peculiarities of service crimes. These are mostly multi-object attacks. The range of their objects is so wide that it embraces almost all law enforcement interests and relationships. On this basis, some legal scholars even concluded that these crimes do not have their own "own" object, that they are qualified types of "common" crimes. The multi-object nature of crimes is expressed in the diverse nature of the harm caused by them, i.e. it causes a multiplicity of socially dangerous consequences. Official crimes generate a variety of negative changes in various areas of public life. The multiplicity of consequences is a distinctive feature of these attacks. It should be taken into account in the legislative process. In unification categorial apparatus existing criminal legislation on liability for service of crime I propose to discuss another issue about transformation is enshrined in the first articles 201, 201.1 and 202 of the criminal code provisions "caused significant harm to rights and legitimate interests of citizens or organizations or legally protected interests of society or the state" to design "significant violation of rights and legitimate interests of citizens and (or) organizations or legally protected interests of society or state." The socio-economic and political grounds for criminalizing violations of the interests of the service in commercial and other organizations are understood as transformations that occurred at the turn of the $X X-X X I$ centuries in the sphere of economy and political system, which determined the emergence of new types of legal entities in the form of primarily private commercial and non-profit organizations with their own management apparatus.
\end{abstract} Address of the author:
Artur Bezverkhov

Keywords: criminal policy, criminal law, official crimes, corruption 


\section{INTRODUCTION}

Service activities are carried out in various spheres of public life and affect all the diversity of rights, freedoms and other socially important goods, relations and values. Therefore, the interests of the service are protected by legal means of different sectoral nature, including criminal law. Over time, certain problems of systematization of Russian criminal legislation on responsibility for crimes against the interests of the service and regulation of criminal responsibility for official crimes become more pronounced. The most acute problem is the dispersion of independent groups of regulations on official crimes in different chapters and sections of the criminal law, which does not always fit into the social and legal essence of the object of these attacks, which requires the placement of the main components of the norms on official crimes within one structural part of the criminal code of the Russian Federation. Special attention is drawn to the gaps in the system of norms on crimes against the interests of the service in commercial and other organizations and on responsibility for abuse of authority in the sphere of activity of commercial and other organizations. The scientific analysis of this problem is also determined by the search for ways to optimize the practice of applying criminal law norms on responsibility At the same time, clarity in distinguishing between crimes and misconduct in the service is extremely important for law enforcement.

\section{ANALYSIS}

Previously, it was easier to remove such uncertainty by relying on the priority of criminal law, which followed from the exclusive isolation of this industry in the legal system. Clarity in distinguishing between crimes and misconduct in the service is essential for law enforcement. However, the issue of distinguishing between official crimes and misdemeanors is one of the poorly developed ones in doctrine and practice. Moreover, the unclear legal relationship between official (official) crimes and official (official, disciplinary) offenses is one of the trends indicated in the development of norms on official offenses. After all, our current law also does not know the strict distinction between official crimes and misdemeanors. The legislative ratio of crimes and other offenses in the field of service interests is still in a sense a ratio of uncertainties, which in itself is "corrupt". At the same time, it should be borne in mind that official misconduct often borders on an official crime of moderate severity, which further exacerbates the problem indicated. Previously, it was easier to remove this uncertainty by relying on the priority of criminal law, which followed from the exclusive isolation of this industry in the legal system. This priority was enshrined in the law. Article 1 of the Fundamentals of the disciplinary legislation of the USSR and the Union republics of 1929 stated: violation of the duties of the service, in particular labor discipline, not prosecuted, entail disciplinary responsibility. This approach is now being superseded by another, according to which the primacy of criminal law is denied. The rejection of the priority of criminal law in the sphere of intersectoral interaction is explained by the fact that criminal law is an integral part of the unified legal system, is applied in the system with other branches of law and, in particular, operates on an equal (parity) basis with the disciplinary and administrative legislation. It is obvious that a clear distinction between crimes and misdemeanors in the service involves specifying the objective features of the composition of official offenses. The concretization here is justified by the need to exclude subjectivity on the part of practitioners, both their mistakes and outright abuses. This approach fits in with the provisions of management theory. According to the latter, the modern trend of management activity is to minimize the human factor. With the development of management technologies, the backlash for the official's personal discretion should become smaller, and the unjustified amount of subjective official discretion should be reduced.

It should be noted that "a significant violation of the rights and legitimate interests of citizens or organizations or the interests of society or the state protected by law" is an imperfect legal construction in the part in which it ignores the hierarchy of values protected by law. By embracing all sorts of harms, this construction does not help to differentiate liability depending on the nature of socially dangerous consequences. In this sense, specifying the content of objective signs of official crimes is a positive approach. However, it cannot be absolutized. Nimia certitudinem ipsam destrucit (too certain a 
certainty destroys itself). It is important to take into account the peculiarities of service crimes. These are mostly multi-object attacks. The range of their objects is so wide that it embraces almost all law enforcement interests and relationships. By the way, on this basis, some legal scholars even concluded that these crimes do not have their own "own" object, that they are qualified types of "common" crimes. The multi-object nature of crimes is expressed in the diverse nature of the harm caused by them, i.e. it causes a multiplicity of socially dangerous consequences. Official crimes generate a variety of negative changes in various areas of public life. The multiplicity of consequences is a distinctive feature of these attacks. It should be taken into account in the legislative process.

In light of this wise legislator in determining the consequences of a crime under part 1 of article 203 of the criminal code, recognizing such "substantial violation of the rights and legitimate interests of citizens and (or) organizations or legally protected interests of society or the state" and, simultaneously, transforming the sign of "the use of violence or threat of use" of the design in the qualifying (part 2 of article 203 of the criminal code). Thus, article 203 of the criminal code, as article 293 of the criminal code, was provided with security much wider range of socially significant attitudes and values.

In unification categorial apparatus existing criminal legislation on liability for service of crime I propose to discuss another issue about transformation is enshrined in the first articles 201 and 202 of the criminal code provisions "caused significant harm to rights and legitimate interests of citizens or organizations or legally protected interests of society or the state" to design "significant violation of rights and legitimate interests of citizens and (or) organizations or legally protected interests of society or state."

The formation of new relations in the life of Russian society in the last quarter of the twentieth century raised the question of reforming the rules on criminal responsibility for official crimes. In fact, the concept of official crime reflected in the Soviet criminal law and the official as the subject of this crime developed in the conditions of the existence of a planned economy with absolute domination of state ownership of the main means of production and the functioning of the command and administrative management system.

The imperfection of the existing system of norms on official crimes in relation to the socio-economic and political conditions that arose at the end of the twentieth century, did not cause any doubts. The relevance and expediency of optimizing legislation on official crimes were generally recognized. Moreover, the improvement of this criminal law institution required new theoretical and applied approaches and legislative solutions that were adequate to the state that was developing during the radical transformations of the socio-economic system and the political system of Russia at the turn of the century.

Criminal code of the Russian Federation was first recognized as criminal, penal, and referring to the group of acts of socially dangerous forms of behaviour in the interests of service in commercial and other organizations (excluding public authorities and organizations with state participation). Attributing encroachments on service in commercial and other organizations to an independent type of crime and describing them in a separate Chapter of the criminal law (Chapter 23 of the criminal code of the Russian Federation) is a legislative approach not previously known to Russian criminal law. Domestic legislation of the pre-Soviet period did not consider violations of the interests of the service in private organizations as a special type (group) of criminal encroachments and did not combine the rules about them into a separate structural part of the criminal law. In Soviet criminal law, there were no rules about these violations at all. This was quite natural in the conditions of denial of private property institutions, private law, and, accordingly, private organizational and legal forms of legal entities.

Modern Russian criminal law provides for strict differentiation of responsibility for official attacks on the interests of public and private organizations. This differentiation is based on the distinction between private and public services, as well as on the distinction between private and public law, the distinction between private and public interests, and the drawing of a watershed between business and government. In my opinion, the exercise of state and municipal power differs from the performance of managerial functions in organizations in terms of its nature, power, and 
consequences. Managing the Affairs of the state and managing the Affairs of a private enterprise or institution are different types of management relationships. The first ones are external, and the second ones are internal. Is it appropriate to rebuild the architecture of the institution of "service crimes", ensuring uniform responsibility for diverse areas of manifestation of illegal acts? I don't think this is necessary. Life itself proves the expediency of legislative differentiation of service interests, on the one hand, in state bodies, local selfgovernment bodies, state and municipal institutions, the Armed Forces of the Russian Federation, other troops and military formations of the Russian Federation, and, on the other hand, service interests in commercial and other organizations that are not a state body, local government body, state or municipal institution or unitary enterprise, state Corporation, state company, as well as a joint-stock company, the controlling stake of which belongs to the Russian Federation, the subjects of the Russian Federation or municipalities. As for internal corporate governance in commercial and other organizations and organizations with the participation of the state (state or municipal institutions or unitary enterprises, state corporations or companies, as well as joint-stock companies in which a controlling stake belongs to the Russian Federation, subjects of the Russian Federation or municipalities), there is also a difference. In this case, the form of ownership of the legal entity (public or private) in whose interests the powers are exercised is of particular importance. Thus, crimes against the interests of the service in commercial and other organizations are an independent type of service crimes committed in the sphere of internal corporate management by the relevant legal entities.

Criminal code of the Russian Federation was first recognized as criminal, penal, and referring to the group of acts of socially dangerous forms of behaviour in the interests of service in commercial and other organizations (excluding public authorities and organizations with state participation). Attributing encroachments on service in commercial and other organizations to an independent type of crime and describing them in a separate Chapter of the criminal law (Chapter 23 of the criminal code of the Russian Federation) is a legislative approach not previously known to
Russian criminal law. Domestic legislation of the pre-Soviet period did not consider violations of the interests of the service in private organizations as a special type (group) of criminal encroachments and did not combine the rules about them into a separate structural part of the criminal law. In Soviet criminal law, there were no rules about these violations at all. This was quite natural in the conditions of denial of private property institutions, private law, and, accordingly, private organizational and legal forms of legal entities.

The social and legal nature of crimes against the interests of the service in commercial and other organizations is expressed in their duality: in economic and managerial features. The economic feature is related to the fact that violations of the interests of the "private" service cause harm or threaten not only economic relations, but also social relations of a non-economic nature. The management feature is that management in private organizations is directly related to the implementation of the powers of management bodies and authorized persons in the interests of private legal entities.

The socio-economic and political grounds for criminalizing violations of the interests of the service in commercial and other organizations are understood as transformations that occurred at the turn of the $X X-X X I$ centuries in the sphere of economy and political system, which determined the emergence of new types of legal entities in the form of primarily private commercial and non-profit organizations with their own management apparatus. Crimes against the interests of the service in commercial and other organizations are an independent type of service crimes committed in the sphere of internal corporate management by the relevant legal entities - corporate organizations and non-profit unitary organizations (with the exception of state and municipal institutions, state corporations, state companies, state and municipal unitary enterprises, joint-stock companies whose controlling interest belongs to the Russian Federation, subjects of the Russian Federation or municipalities). In light of the above, we propose to amend the title of Chapter 23 of the criminal code and call it "Crimes against the interests of the service in corporate and non-profit unitary organizations". The specific object of crimes against the interests of the service in corporate and non-commercial unitary 
organizations is public relations to ensure the legitimate interests of the service in corporate organizations and non-commercial unitary organizations, with the exception of state and municipal institutions, state corporations, state companies, state and municipal unitary enterprises, joint-stock companies whose controlling stake belongs to the Russian Federation, subjects of the Russian Federation or municipalities ${ }^{1}$.

The interests of the service in corporate and noncommercial unitary organizations are understood as an ordered set of legitimate interests that are realized in the course of the organizations ' activities. The interests of the service in terms of Chapter 23 of the criminal code:

1. derive from the interests of the organization itself;

2. directly related to the interests of the founders, members, and employees of the organization;

3. in contact with the interests of investors, creditors, customers and other third parties, whose activity is connected with the activities of the organization.

This set of legitimate interests is based on a goodfaith order of service - the proper exercise of the powers assigned to them by representatives of the management bodies of a legal entity (Egorova, 2006).

In light of the above discussion on the question of recognition in the long term interests of the service generic object service crimes and the allocation of a section of the criminal code "Crimes against interests of service". The new section is proposed to include two chapters:

1. "Crimes against the interests of public service and service in local self-government bodies" and

2. "Crimes against the interests of service in corporate and non-profit unitary organizations".

It is also advisable to discuss the inclusion of abuse of authority in the Chapter on crimes against the interests of the service in commercial and other organizations. Thus the excess of powers should be understood the Commission by a person performing managerial functions in commercial or other organization, of action beyond its powers and have entailed essential infringement of rights and legitimate interests of citizens or organizations or legally protected interests of society or state.

The obvious main trends of systematization of rules concerning official crimes in modern criminal law, that is, a natural stable form of systematization of rules concerning official crimes: the expansion in the criminal code regulations about office crimes, including in connection with anti-corruption measures; the convergence of the two systems of norms on service offences. Thus, on the basis of historical and legal analysis, features of the mechanism of causing harm by official (official) crimes, as well as in order to strengthen the preventive potential of the current legislation, it is proposed to reconstruct the composition of "inaction of the authorities" in Russian criminal law and thereby Orient law enforcement practice to consistently counteract passive forms of deliberate official behavior of a socially dangerous nature. According to these legal scholars, it is advisable to Supplement Chapter 30 of the criminal code provisions on "failure to perform official duties," i.e., the deliberate non-performance (or improper performance) of an official of his duties, which entailed substantial violation of rights and legitimate interests of citizens or organizations or legally protected interests of society or the state. An aggravating circumstance of deliberate nonperformance of official powers should be recognized as official inaction for the purpose of extracting benefits and advantages for yourself or others. It is advisable to include such an aggravating circumstance in the system of qualifying signs of abuse of power. However, all this will require the exclusion from the criminal code of the Russian Federation of the abuse of official powers in order to eliminate the redundancy (duplication) of criminal law prohibitions of socially dangerous official behavior. According to another scientific concept, it is advisable to include an article on deliberate nonperformance of official duties by officials in the draft § 1 "Crimes against public authority, interests

${ }^{1}$ Compare: (Shnitenkov, 2006) 
of public service and service in local selfgovernment bodies" and "Crimes against public authority, interests of public service, service in local self-government bodies and management in commercial and other organizations". The article on deliberate failure to perform managerial duties is proposed to Supplement the draft $\S 2$ "Crimes against the interests of management in commercial and other organizations" of the Chapter "Crimes against public authority, the interests of the public service, service in local government and management in commercial and other organizations". While willful failure to perform managerial duties proposed to be defined as willful failure to perform by a person performing managerial functions in commercial or other organisation, of his duties contrary to the legitimate interests of this organization and in order to extract benefits for themselves or others or harming other persons, if the offense caused substantial harm to rights and legitimate interests of citizens or organizations or legally protected interests of society or the state (Korostelev, 2015).

It appears that the addition of the criminal law provisions of intentional or willful failure to perform, improper performance by a person performing managerial functions in commercial or other organisation, of his duties, possibly with mandatory symmetric addition of Chapter 30 of the criminal code and the legislative solution to the issue of a clear distinction between designated "triad": "the abuse of authority - abuse of authority - willful dereliction of authority."

The classification of crimes against the interests of the service in commercial and other organizations, in particular, as well as the classification of official crimes is not based on a single criterion at all and does not have a single basis for construction. When systematizing the rules on official crimes, the legislator uses several criteria, one giving a major role, the other a secondary importance. Traditionally, when building a system of official crimes, three criteria are used that are associated with the special danger of these attacks: the object of the crime (the main object of the crime, an additional object of the crime or object), the method of committing the crime (or another component of the act), the subject of the crime. Another classification of official crimes, including those provided for in Chapter 23 of the criminal code, is based on a complex basis, which simultaneously includes the interrelated content of the object, the objective side and the subject of the crime. According to this complex basis, there are General, special and alternative service crimes. Classification of crimes against the interests of the service in private organizations is closely related to the processes of speciation of the relevant criminal law norms. Therefore, the classifications of these crimes do not remain unchanged, they are modified and transformed, determining the prospects, trends and strategies for the development of the entire named norm formation.

\section{CONCLUSION}

In light of the above, you need a clear legislative the ratio of norms on criminal responsibility for crimes against interests of private organizations and crimes against interests of public service and service in local governments; ensuring, on the one hand, convergence of legal rules on responsibility for crimes against interests of service in private and public organizations, and with another - a strict differentiation of criminal liability for these related criminal assault; clarification of the notion of the person performing managerial functions in commercial or other organization, in order to exclude from the criminal legislation of Russia of discrepancies, for example in terms of legislative language on the implementation of a special subject called managerial functions "in a commercial or other organization" (part 1 of article 201, part 1 of article 201.1, paragraphs 1 and 5 of article 204 of the criminal code) and "in a commercial or other organization, as well as in non-profit organization" (note 1 to article 201 of the criminal code); improving the structure of regulations that provide for criminal liability for the analyzed crimes, in the light of the allocation of General and special types of the corresponding type of official encroachments and the location of regulations on them in a certain sequence.

\section{WORKS CITED}

Egorova, N. (2006). Teoreticheskiye problemy ugolovnoy otvetstvennosti za prestupleniya lits, vypolnyayushchikh upravlencheskiye funktsii [Theoretical problems of criminal responsibility for crimes of persons performing managerial functions]. Volgograd. 
Korostelev, V. (2015). Sistema sluzhebnykh prestupleniy po ugolovnomu pravu Rossii: voprosy istorii, teorii, praktiki [System of official crimes in the criminal law of Russia: questions of history, theory, practice: monograph]. Moscow: Yurlitinform.

Shnitenkov, A. V. (2006). Otvetstvennost' za prestupleniya protiv interesov gosudarstvennoy sluzhby $v$ kommercheskikh i inykh organizatsiyakh [Responsibility for crimes against interests of public service and the interests of service in commercial and other organizations]. SPb.: Publishing house of R. Aslanov "Legal center Press".

Received for publication: $\quad 25.02 .2020$

Revision received: $\quad 09.05 .2020$

Accepted for publication: $\quad 01.07 .2020$

\section{How to cite this article?}

Style - APA Sixth Edition:

Bezverkhov, A. G. (2020, July 15). Current Russian policy in the area of counter-official crimes. (Z. Cekerevac, Ed.) MEST Journal, 8(2), 18-24. doi:10.12709/mest.08.08.02.03

Style - Chicago Sixteenth Edition:

Bezverkhov, Artur Gennadevich. 2020. "Current Russian policy in the area of counter-official crimes." Edited by Zoran Cekerevac. MEST Journal (MESTE) 8 (2): 18-24. doi:10.12709/mest.08.08.02.03.

Style - GOST Name Sort:

Bezverkhov Artur Gennadevich Current Russian policy in the area of counter-official crimes [Journal] // MEST Journal / ed. Cekerevac Zoran. - Belgrade - Toronto : MESTE, July 15, 2020. - 2 : Vol. 8. - pp. 18-24.

Style - Harvard Anglia:

Bezverkhov, A. G., 2020. Current Russian policy in the area of counter-official crimes. MEST Journal, 15 July, 8(2), pp. 18-24.

Style - ISO 690 Numerical Reference:

Current Russian policy in the area of counter-official crimes. Bezverkhov, Artur Gennadevich. [ed.] Zoran Cekerevac. 2, Belgrade - Toronto : MESTE, July 15, 2020, MEST Journal, Vol. 8, pp. 18-24. 